\title{
Analysis and Forecast of Railway Passenger Volume Using System Dynamics
}

\author{
Xiaoyu Zhi \\ School of Traffic and Transportation, Beijing Jiaotong University, Beijing 100044, China
}

\begin{abstract}
A system dynamics model is established based on the analysis of main factors and their relationships in the railway passenger transportation system. The causal loop diagram, flow chart and the Structural equations were established, and relevant parameters are determined. The model is verified by comparison of historical statistical and simulated data. Finally passenger volumes of next five years in railway transport system are forecasted. The results show that the model is effective and feasible. System dynamics model meets the characteristics of railway passenger transport system. It can be used to forecast short-term railway passenger volume well.
\end{abstract}

Keywords-system dynamics; railway passenger volume; forecast; number of railway staffs;mileage

\section{INTRODUCTION}

System dynamics is a kind of method about nonlinear statistical regression analysis. By analyzing the causal relationship between system elements, it sets up system dynamics model, and grasps the operation rule of the system. The main applications of system dynamics in the field of traffic and transportation are: Xin Guo (2013, p. 31) make a research on the pricing of passenger dedicated line using system dynamics; Changfeng Shui (2005, P. 74) used system dynamics to make a forecast on railway passenger volumes; Allan. D. Chasey (1997, p. 143) apply system dynamics on transportation system considering the problem complexity and feedback loop caused by the process that the service level of transportation making an influence on social and economic system. The variables and parameters of the model formed the basis of the target data, which making an aid decision. Philippe. A. Bonnefoy (2010, p. 1021) put forward dynamic models of multiple aviation hubs worldwide, helping aviation hub to formulate effective development strategy in the future.

Passenger volume forecast is the important precondition for strengthening transportation market analysis research. Mastering the development status and the amount of traffic of the transportation market in time is the effective way for the transport industry adapting to the market environment actively and identifying the development direction in the competition. It also the foundation and important link of setting relevant planning measures and playing a role on the public welfare. Whether to meet passenger demands is related to the public welfare, and to seek the optimal number of railway workers and operating mileage is related to operation benefit.

In general, passenger volume forecast mainly uses historical data to predict future passenger volume. There are many factors which can affect the railway passenger volume. This paper only analyzes the factors such as population, travel speed, transport capacity of rail network, and the railway transport price. At the same time, with the development of railway transportation, whether the change of passenger volume is related to the number of railway staffs will also be discussed, which is relevant to the ownership of railway passenger train and upgrading costs. So three level variablespassenger volume, number of railway staffs, operation mileage are selected in this paper. And auxiliary variables include population, travel speed, the price of railway transportation, transportation capacity of railway network and so on.

\section{ANALYSIS AND PREDICTION OF RAILWAY PASSENGER VOLUME USING SYSTEM DYNAMICS}

Set the process of making system dynamics model of railway passenger volume forecasting according to the main steps using system dynamics to solve the problem. As shown in Figure 1.

\section{A. Cause-And-Effect Relation Chart of Railway Passenger} Volume Forecast

(1) Draw the cause-and-effect relation chart

There are many factors affecting railway passenger volume. The major is transport demand and supply. Considering from the perspective of demand the main factor is population. And from the perspective of supply, it's mainly influenced by investment of passenger railway transport, which has further influence on transport capacity of rail network and railway transport price.(Wang, 2014, p. 11) After a systematic analysis, establish the cause-and-effect relation chart of railway passenger volume forecast, show in Figure 2. Figure 2intuitively reflects the internal mechanism of dynamic development of railway passenger volume forecast system. 


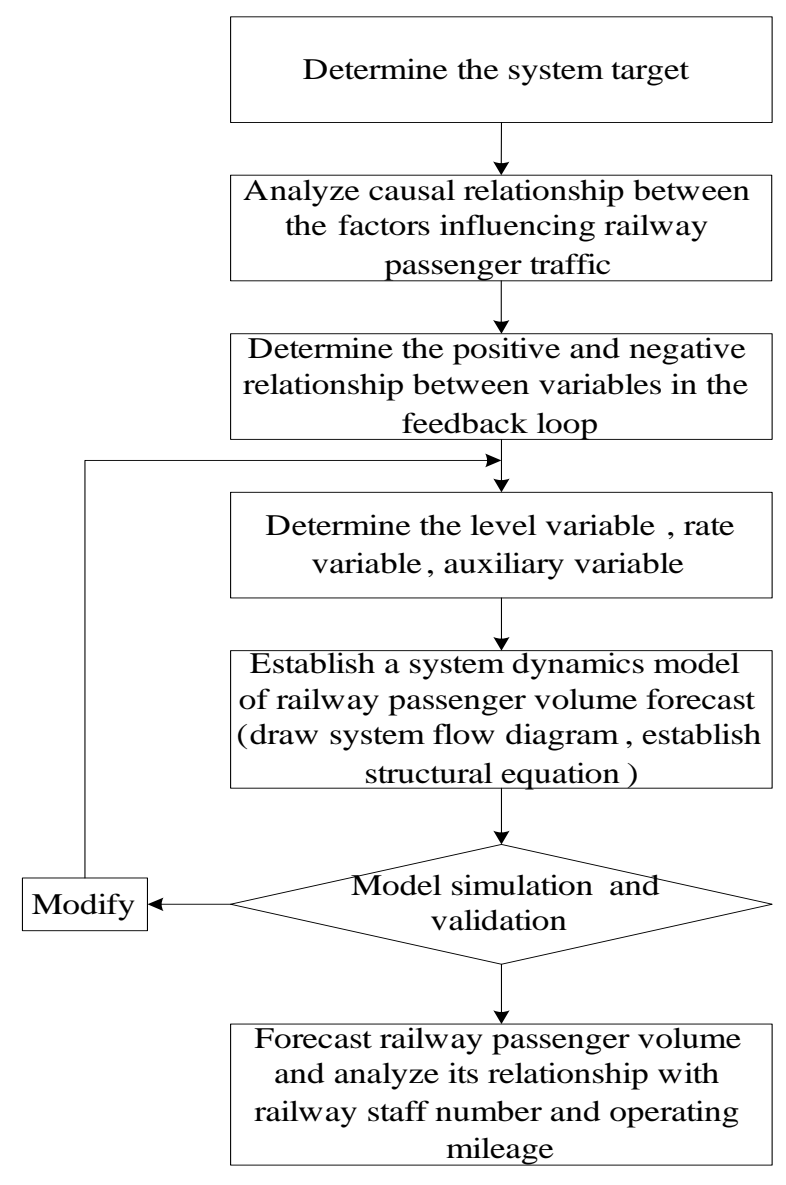

FIGURE I. FLOW CHART OF SYSTEM DYNAMICS MODEL OF RAILWAY PASSENGER VOLUME

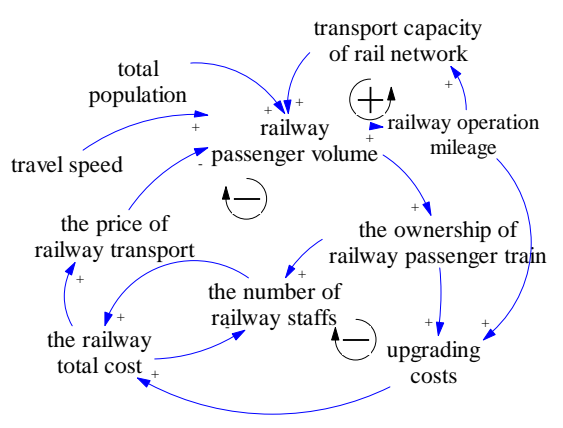

FIGURE II. DRAW THE CAUSE-AND-EFFECT RELATION CHART

\section{(2) Feedback loop analysis}

This paper mainly studies the change of the railway passenger volume, the cause-and-effect relation chart mentioned above has two negative feedback loop and one positive feedback loop bound up with railway passenger volume.

Negative feedback loop 1:railway passenger volume + the ownership of railway passenger train + the number of railway staffs (upgrading costs) + the railway total cost + the price of railway transport__ railway passenger volume

Negative feedback loop 2: railway passenger volume + operation mileage + upgrading costs $\underset{\longrightarrow}{\longrightarrow}$ the railway total cost + the price of railway transport - railway passenger volume

Meaning: Both of the two negative feedback loop have an influence on the ticket price by affecting the railway total cost. In one word, the rise of the transportation price restrain the increase of railway passenger volume.

Positive feedback loop: railway passenger volume _ operation mileage $+\underset{+}{+}$ transport capacity of rail network railway passenger volume

Meaning: This loop reflect that improving transport capacity of rail network helps attract passenger, and the increase the passenger volume. All in all, the railway passenger volume will be improved by this loop, so it is a positive feedback loop.

System flow chart of railway passenger volume forecast

(1) Draw the system flow chart

On the basis of the above analysis of the cause-and-effect relation chart, the flow chart of the passenger volume forecast made by Vensim software is given below(Figure 3), with consideration of the principle of one to one correspondence for the variables in the relation chart and flow chart.

(2) System flow chart analysis

It can be seen clearly from the above system flow chart that there are three level variables and relative rate variables, the rest are all auxiliary variables, which exert an influence on the level variables through rate variables. 


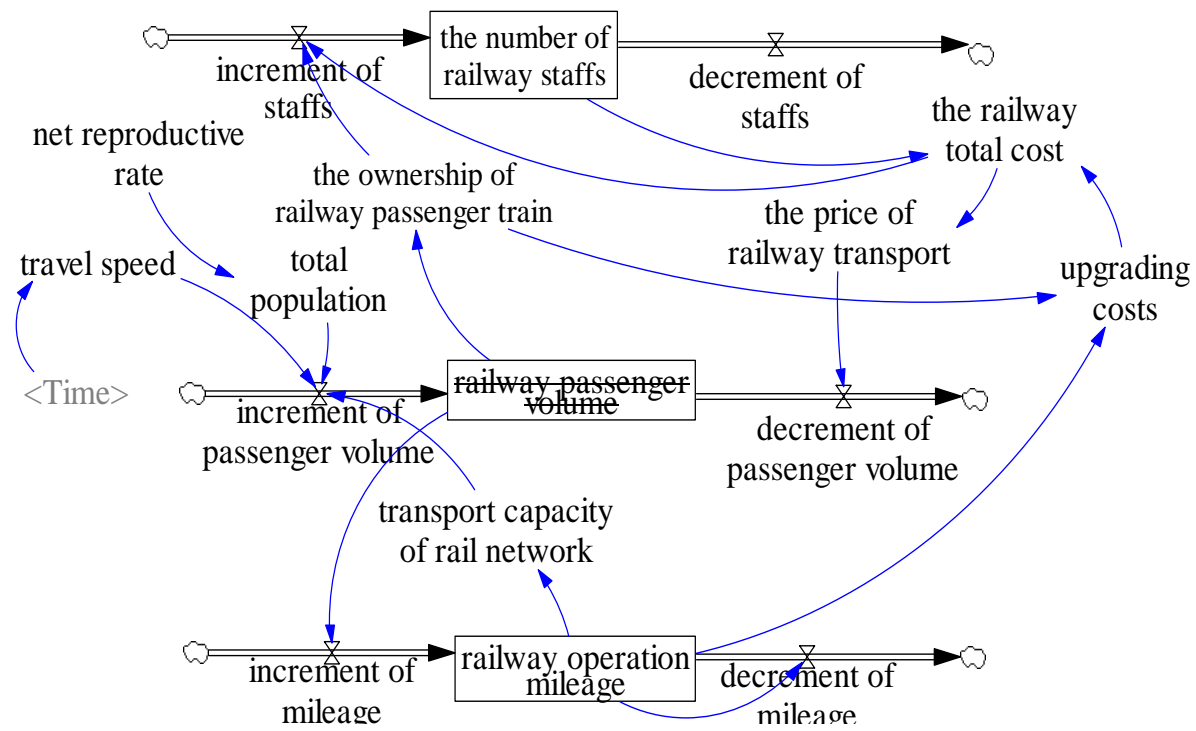

FIGURE III. SYSTEM FLOW CHART OF RAILWAY PASSENGER VOLUME ANALYSIS AND FORECAST

B. Structural Equation of Railway Passenger Volume Analysis and Forecast

(1) Level equation (L)

$\mathrm{L}$ : the number of railway staffs. $\mathrm{K}=$ the number of railway staffs. J+DT*(increment of staffs. JK -decrement of staffs. JK)

$\mathrm{L}$ : railway passenger volume. $\mathrm{K}=$ railway passenger volume .J+ DT*(increment of passenger volume .JK decrement of passenger volume. JK)

$\mathrm{L}$ : railway operation mileage. $\mathrm{K}=$ railway operation mileage .J+ DT*(increment of mileage. JK -decrement of mileage .JK)

(2) Rate equation (R)

$\mathrm{R}$ : increment of staffs $. \mathrm{KL}=$ the ownership of railway passenger train .K- the railway total cost. $\mathrm{K}^{*} 10^{\wedge}-7$

$\mathrm{R}$ : decrement of staffs. $\mathrm{KL}=2.5$

$\mathrm{R}$ : increment of passenger volume .KL $=50 *$ travel speed. $\mathrm{K}+10^{\wedge}-2 *$ total population $. \mathrm{K}+$ transport capacity of rail network .K

$\mathrm{R}$ : decrement of passenger volume. $\mathrm{KL}=$ the price of railway transport. $\mathrm{K} * 3 * 10^{\wedge} 4$

$\mathrm{R}$ : increment of mileage. $\mathrm{KL}=0.2^{*} 10^{\wedge}-5^{*}$ railway passenger volume. $\mathrm{K}$

$\mathrm{R}$ : decrement of mileage .KL $=0.015^{*}$ railway operation mileage. $\mathrm{K}$

(3) Auxiliary equation (A)

A: ownership of railway passenger train. $\mathrm{K}=1.69+0.2005^{*} 10^{\wedge}-4 *$ railway passenger volume. $\mathrm{K}$
A: the railway total cost $. K=$ upgrading costs. $\mathrm{K}+100000^{*}$ the number of railway staffs. $K$

A: travel speed. $\mathrm{K}$

$=([(2000,60)-$

(2012,80)],(2000,66),(2001,66.3),(2002,66.6),(2003,67),(2004, 71.7),(2005,73.7),

(2006,74.2),(2007,74.7),(2008,78.8),(2009,69.6),(2010,70.8 )$,(2011,71.5),(2012,70.8))$

A: total population .K=126743+net reproductive rate. $\mathrm{K} * 900$

A: transport capacity of rail network $. K=5 * 10^{\wedge} 2 *$ operation mileage. $\mathrm{K}$

A: the price of railway transport $. \mathrm{K}=$ the railway total cost . $\mathrm{K}^{*} 10^{\wedge}-9$

(4) Constant

$\mathrm{N}$ : the number of railway staffs $=187.1$

$\mathrm{N}$ : railway passenger volume $=105073$

$\mathrm{N}$ : operation mileage $=6.87$

\section{Data Collection and Parameter Determination}

Collect data from $<$ China Statistical Yearbook $>$ and sort as Table 1:

The rest variables can't be find in <China Statistical Yearbook> and be defined indirectly, for example, define a particular indicator is a linear dependent variable of operational mileage, which will be used to measure the transport capacity of rail network.

Data processing and the method of parameter determination: 
TABLE I. DATA COLLECTION AND SORTING

\begin{tabular}{ccccccc}
\hline $\begin{array}{c}\text { passenger } \\
\text { volume(ten } \\
\text { thousand } \\
\text { people) }\end{array}$ & $\begin{array}{c}\text { population } \\
\text { (ten thousand } \\
\text { people) }\end{array}$ & $\begin{array}{c}\text { operation } \\
\text { mileage ten } \\
\text { thousand } \\
\text { kilometers }\end{array}$ & $\begin{array}{c}\text { travel } \\
\text { speed(km/h } \\
\text { ) }\end{array}$ & $\begin{array}{c}\text { the number of } \\
\text { railway } \\
\text { staffs(ten } \\
\text { thousand } \\
\text { people) }\end{array}$ & $\begin{array}{c}\text { ownership } \\
\text { of railway } \\
\text { passenger } \\
\text { train(car) }\end{array}$ & $\begin{array}{c}\text { year } \\
105073\end{array}$ \\
126743 & 6.87 & 66 & 187.1 & 35989 & 2000 \\
105155 & 127627 & 7.01 & 66.3 & 183.7 & 36856.8 & 2001 \\
105606 & 128453 & 7.19 & 66.6 & 180.7 & 37724.6 & 2002 \\
97260 & 129227 & 7.3 & 67 & 178.4 & 38592.4 & 2003 \\
111764 & 129988 & 7.44 & 71.7 & 169.6 & 39460.2 & 2004 \\
115583 & 130756 & 7.54 & 73.7 & 166.6 & 40328 & 2005 \\
125656 & 131448 & 7.71 & 74.2 & 165.3 & 42328 & 2006 \\
135670 & 132129 & 7.8 & 74.7 & 174.1 & 44328 & 2007 \\
146193 & 132802 & 7.97 & 78.8 & 173.2 & 46328 & 2008 \\
152451 & 133450 & 8.55 & 69.6 & 185 & 48328 & 2009 \\
167609 & 134091 & 9.12 & 70.8 & 175.6 & 50391 & 2010 \\
186226 & 134735 & 9.32 & 71.5 & 176.1 & 52838 & 2011 \\
189337 & 135404 & 9.76 & 70.8 & 179.3 & 55764 & 2012 \\
\hline
\end{tabular}

Adopt the table function to express travel speed; Use linear regression equation of excel software, input one variable data (from 2000 to 2012), and then input data (from 2000 to 2012) of all dependent variables, determining the coefficient of each dependent variable of the equation. By this method, the function can be fit out. Use the function as the structural equation in Vensim software. There mainly be linear equation using this fitting method, the error may be larger, To make the initial value of the equation meet with the data in China Statistical Yearbook, rule the equation intercept to be the data of 2000, but the result of this method conforms to the overall trend about the change of relevant variables, and effectively reflects the relationship between each variable.

\section{Model Test And Simulation Analysis}

Draw the flow chart and input the structure equation using the Vensim software, define the initial value of every level variable (the unit of all data in the processis ten thousand). The simulation results are as follows.

\section{(1) Model fitting test}

It can be find from Figure 4 that the railway passenger volume is about 1.05 billion people in 2000 and 2 billion people in 2012, while the actual data is 1.05073 billion people and 1.89337 billion people. So the difference between the data in the trend figure and actual data is small, having a certain credibility. The error of model is small.

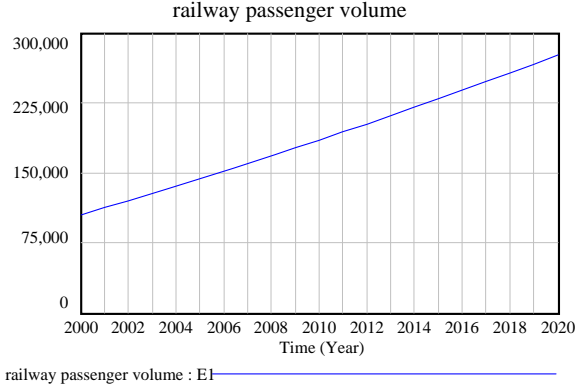

FIGURE IV. RAILWAY PASSENGER VOLUME

Make a forecast of railway passenger volume about five years, show in Table 2.

TABLE II. FORECAST OF RAILWAY PASSENGER VOLUME

\begin{tabular}{llll}
\hline $\begin{array}{l}\text { Time } \\
\text { (Year) }\end{array}$ & $\begin{array}{l}\text { railway } \\
\text { passenger } \\
\text { volume }\end{array}$ & Time (Year) & $\begin{array}{l}\text { railway } \\
\text { passenger } \\
\text { volume }\end{array}$ \\
\hline 2013 & 211204 & 2017 & 247649 \\
2014 & 220105 & 2018 & 257131 \\
2015 & 229142 & 2019 & 266774 \\
2016 & 238321 & 2020 & 276585 \\
\hline
\end{tabular}

(2) Analysis of level variables change trend

It can be seen from Figure 5 that with the increasing of the railway passenger volume, the number of railway staffs doesn't increase correspondingly; actually the trend of the number is rising firstly and then falling down. While the variation trend of operation mileageis basically consistent with that of railway passenger volume. 


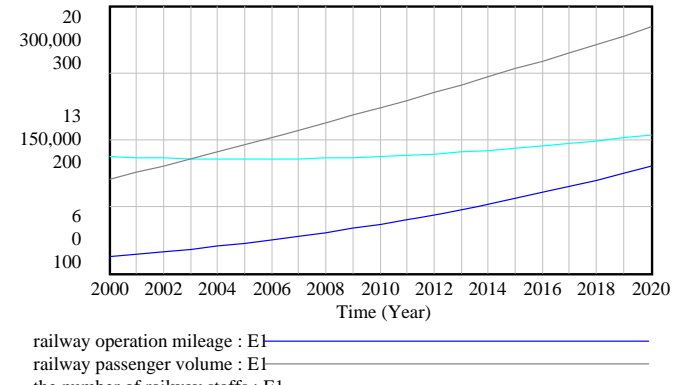

the number of railway staffs : $\mathrm{E} 1$

\section{FIGURE V. COMPARISON OF DIFFERENT LEVEL VARIABLES}

(3) Sensitivity analysis-influence caused by travel speed

In the software, we can also change some of the key parameter to analyze the influence of the parameters on our research. For instance, the travel speed in recent years is about $70 \mathrm{~km} / \mathrm{h}$, assuming that it increases to $80 \mathrm{~km} / \mathrm{h}$, observe the change of passenger volume on the basis of unchanging other relevant relationships.

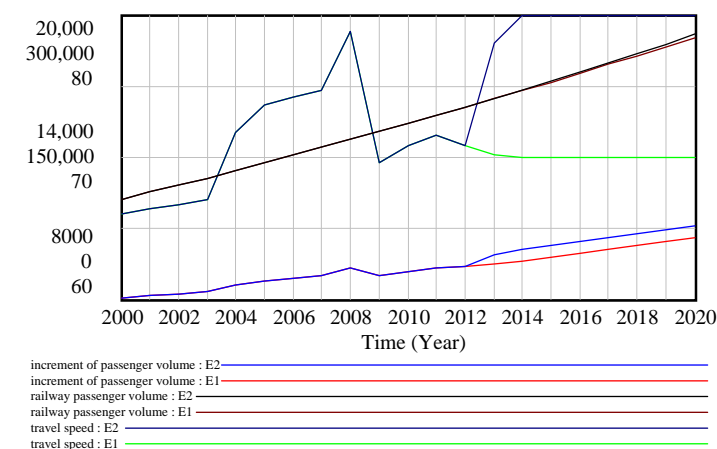

FIGURE VI. THE RELATIONSHIP BETWEEN THE CHANGE OF TRAVEL SPEED AND THE PASSENGER VOLUME

In Figure 6, the green line and the white line respectively represent the situation that the travel speed is $70 \mathrm{~km} / \mathrm{h}$ and $80 \mathrm{~km} / \mathrm{h}$ after 2012, observe the trend of the blue line and the red line (change of the increment of passenger volume), the improvement of travel speed make the growth of passenger volume increment increase a little. The brown line and black line represent the change of the passenger volume, with the improvement of travel speed, the volume have an invisible increment. It may be caused by negative feedback loop. It illustrates that the improvement of travel speed play a role in attracting passengers, meanwhile it adds pressure to investment, which results in the rise of ticket price, and this will restrict the soaring increment of passenger volume.

\section{CONCLUSIONS}

This paper research on the railway passenger volume analysis and forecast according to the principle of system dynamics, and realize it using Vensim software. Taking full consideration of the influence factors of railway passenger volume and the relationship among the factors, this paper establishes a system dynamics model of railway passenger volume forecast, predicts railway passenger volume in the next five years accurately, and analyzes the relationship between passenger volume and other variables: the railway passenger volume will keep increasing but be not soar for the constrain of negative loop, the variation tendency of railway passenger volume and railway operation mileage are almost the same. But they don't have a positive correlation with the number of railway staffs. So the increase of passenger volume have a more direct reflect on the requirement for railway infrastructure construction like operation mileage. The above conclusions can provide reference for railway departments to transportation planning, marketing, track line reconstruction.

Characteristic of system dynamics model better conforms to the characteristics of railway passenger transport system, using system dynamics can perform good short-term prediction of railway passenger volume. However, this study is still preliminary and has its limitations. Further study will be pursued in three directions. First, the model should be more accurate by in-depth selection of variables and parameters. Second, sensitivity analysis should be more comprehensive. Third, the model can incorporate other related aspects, i.e. energy.

\section{REFERENCES}

[1] Xin Guo. (2013). Passenger Railway Traffic Volume Forecast Model Based on LOGIT and System Dynamics. Journal of Beijing institute of technology,S1,31-34.

[2] Changfeng Shui, Yuanhua Jia, Xu Xiao.(2005). Research on System Dynamic Prediction Model of Railway Passenger Traffic. Comprehensive Transportation, 3,73-75.

[3] Allan D Chasey,Jesus M,De La Garza,Donald R Drew. (1997).Comprehensive Level of Service: Needed Approach for Civil Infrastructure Systems.Journal of Infrastructure Systems, 4:143-153.

[4] Bonnefoy A,Neufville,John HansmanR. (2010). Evolution and Development of MultiairportSystems:Worldwide Perspective.Journal of Transportation Engineering,11,1021-1029.

[5] Wanxiang Wang. (2014).System Dynamic Prediction of Railway Passenger Volume. Journal of Dalian Jiaotong University,5,10-12+16. 